\title{
El cuerpo femenino fotografiado
} por mujeres artistas*

\section{José Horacio Rosales Cueva** \\ Beatriz Núñez Arce ${ }^{* * *}$}

Este artículo expone parte de los resultados de una investigación semiótica de la representación del cuerpo en la fotografía creada entre 2010 y 2020 por artistas latinoamericanas. Los objetivos de la pesquisa son comprender y modelizar cómo es configurada la corporeidad femenina en la fotografía digital de creadoras que, específicamente, emplean medios virtuales para divulgar las propias obras. El método de investigación cualitativo-interpretativo se encaminó al estudio de casos que correlaciona fotógrafa, fotografía y medios digitales. El procedimiento analítico se realizó con la semiótica visual que aborda los elementos figurativos y narrativos de las imágenes y enfatiza las prácticas enunciativas en entornos socioculturales de intercambio de objetos significantes. Los resultados del estudio de cada imagen seleccionada y constituyente de la muestra investigada llevaron a construir una teoría fundamentada que engloba las convergencias de elaboración y divulgación de las fotografías de la muestra. Este artículo expone los resultados de tal procedimiento practicado con unas esas imágenes, Sin título, que integra la serie fotográfica elaborada por Victoria Razo sobre las marchas de mujeres del 8 de marzo de 2020 en Ciudad de México. El análisis semiótico realizado aporta recursos a la comprensión de prácticas enunciativas visuales en escenarios de reivindicaciones sociales y permite algunas conclusiones sobre la iconografía, con atributos del hacer documental y artístico, del cuerpo-sujeto de mujer, mientras que las creadoras aprovechan los medios digitales para la exhibición artística y dinamizar la comprensión del observador de las gestas reivindicativas de los derechos femeninos.

Palabras clave: cultura, arte, semiótica, cuerpo femenino, fotógrafas, fotografía. doi 10.11144/javeriana.mavae17-1.cffm

Fecha de recepción: 17 de junio de 2021

Fecha de aceptación: 6 de septiembre de 2021

Disponible en línea: 1 de enero de 2022

* Artículo de investigación que hace parte del proyecto Semiótica del cuerpo en la fotografía creada entre 2010 y 2020 por artistas latinoamericanas, de la Maestría en Semiótica y del Grupo de Investigación Ergonomía, Producto y Significado de la Universidad Industrial de Santander.

** Licenciado en Educación por la Universidad de los Andes (Venezuela), magíster en Estudios Semiológicos, especialista en Docencia Universitaria por la Universidad Industrial de Santander, Diploma de Estudios Avanzados en Semiología de las Interacciones Culturales y doctor en Ciencias del Lenguaje por la Universidad de Limoges. Miembro del Grupo de Investigación Ergonomía, Producto y Significado (GEPS) y profesor titular de la Universidad Industrial de Santander. Orcid: 0000-0003-1250-1120. Correo electrónico: jrosales@uis.edu.co.

*** Licenciada en Educación Básica con énfasis en Educación Artística por la Corporación Universitaria Minuto de Dios (Uniminuto) y maestranda en Semiótica de la Universidad Industrial de Santander. Correo electrónico: Orcid: 0000-0001-8246-7365. beatricenunezarce@gmail.com.

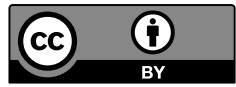




\section{The Female Body Photographed by Female Artists}

This paper presents part of the results of a semiotic investigation on the representation of the body in photography, created between 2010 and 2020 by Latin American female artists. The objectives of the research are to understand and model how female corporeity is configured in the digital photography of creators who, specifically, use virtual media to disseminate their own works. The qualitative-interpretive research method was aimed at the study of cases that correlates the photographer, photography, and digital media. The analytical procedure was carried out with visual semiotics, which addresses the figurative and narrative elements of the images and emphasizes the enunciative practices in sociocultural environments of exchange of significant objects. The results of the study of each selected and constituent image of the investigated sample led to the construction of a grounded theory that encompasses the convergences of elaboration and dissemination of the photographs of the sample. This paper presents the results of such a procedure, carried out with some of those images, without a title, which is part of the photographic series prepared by Victoria Razo on the women's marches on March 8, 2020, in Mexico City. The semiotic analysis conducted provides resources for understanding visual enunciative practices in scenarios of social demands and allows drawing some conclusions about the iconography, with attributes of documentary and artistic making, of the female body-subject, while the creators use digital media for artistic exhibition and to encourage the observer's understanding of the deeds of demands for women's rights.

Keywords: culture, art, semiotics, female body, female photographers, photography.

\section{O corpo feminino fotografado por artistas mulheres}

Este artigo expõe parte dos resultados de uma investigação semiótica da representação do corpo na fotografia realizada entre 2010 e 2020 por artistas latino-americanas. Os objetivos da pesquisa são compreender e modelar como a corporeidade feminina se configura na fotografia digital de criadoras que, especificamente, utilizam as mídias virtuais para divulgar seus próprios trabalhos. 0 método de pesquisa qualitativo-interpretativo foi direcionado ao estudo de casos que correlaciona fotógrafo, fotografia e mídia digital. 0 procedimento analítico foi realizado com a semiótica visual que aborda os elementos figurativos e narrativos das imagens e enfatiza as práticas enunciativas em ambientes socioculturais de troca de objetos significativos. Os resultados do estudo de cada imagem selecionada e constituinte da amostra investigada levaram à construção de uma teoria fundamentada que engloba as convergências de elaboração e divulgação das fotografias da amostra. Este artigo expõe os resultados de tal procedimento realizado com algumas dessas imagens, sem título, que faz parte da série fotográfica preparada por Victoria Razo nas marchas das mulheres de 8 de março de 2020 na Cidade do México. A análise semiótica realizada fornece recursos para a compreensão das práticas enunciativas visuais em cenários de demandas sociais e permite algumas conclusões sobre a iconografia, com atributos do fazer documental e artístico, do corpo-sujeito feminino, enquanto os criadores se valem dos meios digitais para a mostra artística e para estimular a compreensão do observador sobre as demandas dos direitos das mulheres.

Palavras-chave: cultura, arte, semiótica, corpo feminino, fotógrafas, fotografia. 


\section{Introducción}

> Los actores sociales, según el modo de hacer y ser, cuestionan y replantean el lugar y sentido de sí mismos en el mundo, ocupaciones que involucran una visión política de aspectos biológicos y socioculturales con la que se defiende la igualdad de derechos y la dignidad humana (Pleyers 2018). Con ritmos correspondientes a la historia de las comunidades, diversas prácticas simbólicas como las artísticas se convierten en escenarios de dramáticos cuestionamientos de valores y de las apuestas por la solución a problemas ancestrales como la cosificación de las personas, las tensiones entre las identidades sexuales, lo mismo que la urgencia de la práctica real de la equidad. En este horizonte, la fotografía, como un objeto mediador de sentido, expone la relación problemática de los cuerpos sensibles con la realidad de diversos ámbitos intersubjetivos. Esta dinámica alrededor de la corporeidad como lugar de proliferación del sentido encuentra siempre una rica manifestación en el arte, lo que no desmaya en las obras de los artistas, de finales del siglo $X X$ y principios del siglo XXI, que llegan a condenar el efectismo y la artificialidad engañosa, pero que consideran también las consecuencias culturales y políticas de las lecturas del cuerpo y de las marginalidades más osadas en que este se implica (Alonso 2017).

La representación del cuerpo femenino ha protagonizado infinidad de obras fotográficas creadas por hombres y mujeres. Cuando las artistas enuncian desde y con la propia corporalidad, pueden hacerse partícipes en un discurso que se rebela frente a los modos en que el arte ha tratado la feminidad a lo largo de la historia. En este devenir, está presente el problema que Berger (2016) reconoce como la presencia del hombre en la manera en que la mujer se mira y que la convierte en "un objeto visual, una visión" (27) o, según el fotógrafo Hans Bellmer, en una imagen de la mujer condicionada por la imagen del hombre que la desea (citado en González-Moreno 2017, 74). La representación del ser mujer sería tratada consecuente y usualmente como un cuerpo-objeto unificado, como una masa orgánica unida a alguna pasión común. Frente a esto la respuesta de las artistas consiste en representar cuerpos femeninos con un trabajo de captación y producción de la imagen visual orientado a una búsqueda de sentidos diferentes frente a experiencias reales y de luchas sociales. En estas formas alternativas de construcción, se trata de una representación partitiva de la panoplia orgánica o de un cuerpo que integra todo lo femenino, que representa al cuerpo-sujeto que siente y padece por sí solo (Landowski 2015, 143) y no a un cuerpo-objeto.

En esta búsqueda, las artistas hacen visible la propia corporalidad y la de las congéneres en escenarios de luchas cotidianas y artísticas, con modos de representación que hacen visibles otras sensibilidades, percepciones y modos de construir las identidades. 
Si el cuerpo de la mujer es problemático en el arte visual del mundo contemporáneo (Sheets 2016), incluso cuando se trata de la representación de la organicidad diferenciadora de los sexos, más lo es en el ámbito específico del arte latinoamericano, con una complejidad extraordinaria de tensiones entre sistemas de creencias modernas y premodernas, en que es dramática también la figura de la mujer artista, tratada, al igual que en muchas partes del mundo, como marginal o indeseable, asunto que es denunciado hoy con respecto de las grandes instituciones del arte (Giunta 2018; Guerrilla Girls 2020; Reilly 2015). Pese a esto, y tal vez por ello, entre otras muchas razones, las artistas latinoamericanas de comienzos de siglo XXI crean fotografías que hablan de sí mismas y las promueven en escenas de intercambio simbólico, movidas por estrategias identificables y esquematizables a posteriori por los estudios científicos.

La crítica dirigida a la representación del cuerpo de la mujer en el arte tiene muchos antecedentes, en especial desde la aparición y el fortalecimiento de los movimientos feministas. El descubrimiento de la fotografía en 1826 significó el desarrollo y uso de una tecnología de registro de imágenes visuales que trajo consigo un conjunto de cambios en el modo de mirar el mundo a través de la lente fotográfica (Sontag 2011). Este tipo de configuraciones significantes ha sido valioso para los estudios de género y las formas de mediación de valores culturales que encuentran, a finales del siglo XX, la llegada de la fotografía y edición digital y la masificación de los medios virtuales. Esto permitió que la fotografía pasara de los dominios privados a convertirse en un objeto de uso público (Marzal 2012) y que el cuerpo, capturado en ella, fuera más claramente asumido por el modo en que es experimentado y en que se le hace participar en las narrativas visuales fijas y en movimiento.

Las representaciones contemporáneas del cuerpo en ámbitos artísticos y de consumo oscilan problemáticamente entre el ejercicio del poder, la subjetividad y la cosificación, temas centrales de creadores e investigadores como Allochis (2017), D’Angelo (2010) y Palazón (2017), quien busca comprender la relación de la corporeidad con el placer visual del observador. La visión de las mujeres en la imagen artística y en la cultura visual (Martínez 2014) responde a una genealogía social de representación y al imaginario pictórico del cuerpo femenino (Val 2011), y se interseca con la manifestación de una subjetividad controlada por el discurso verbo-visual publicitario (Cely 2015), que replantea los cánones de belleza con la masificación de estereotipos (Márquez 2007). El cuerpo de las mujeres explorado fotográficamente y de manera diferente por las artistas, en especial desde la segunda ola feminista de la década de 1960, ha enfrentado el problema de la divulgación de los trabajos en los museos y las galerías de arte. No obstante, en el siglo XXI, estos espacios dan mayor participación y reconocimiento a las obras artísticas hechas por mujeres, aunque sigue siendo evidente la desigualdad entre las exposiciones de mujeres y hombres, como demuestran Halperin y Borns (2019). En las inmediaciones de esta dinámica, aparecen valiosos estudios que exponen la historia del arte hecho por mujeres (Magaña 2014), usualmente realizadas por mujeres como Alario (2008), Antivilo (2013), Bautista (2018), Cuesta (2012), Gajewski (2015) y Torrado (2012), por ejemplo, quienes abordan la presencia de la mujer en el arte exhibido en el Museo Reina Sofía de Madrid; Muñoz y González-Moreno (2014) se han interesado en la relación entre la mujer-modelo y la fotógrafa, asunto en que convergen la identidad femenina en la fotografía (González-Moreno 2017), el enfoque de género fotográfico (Campo 2017), la disidencia y la resistencia en el arte de las mujeres (Ballester 2017).

En la actualidad, se han realizado investigaciones semióticas sobre la fotografía en la era digital (Pérez 2011) y la divulgación de estas producciones visuales en los espacios virtuales (O’Hagan 2018), donde aparecen implicaciones éticas y epistémico-metodológicas de estas formas de representación como objeto de análisis en ciencias sociales (Schwarz 2016), dado 
que comprender el contenido de las fotografías es una labor de investigación que se articula también con los modos específicos de divulgación en entornos enunciativos. Esta correspondencia entre creación y entorno sociocultural aparece en investigaciones sobre la fotografía documental como recurso en la obra de mujeres artistas (Clemente-Fernández, Febrer-Fernández y Martínez-Oña 2018), el discurso femenino en el autorretrato fotográfico (Báscones 2018), la fotografía femenina como legado generacional (Vicente 2018) y el surrealismo redefinido en el siglo XXI por la fotografía de mujeres sobre mujeres (Palumbo 2020), entre otras pesquisas realizadas mayormente en España, Inglaterra, Estados Unidos y Francia. En estos trabajos, se reconoce cómo la fotografía hecha por las artistas está fortalecida por el auge de la imagen digital que explora reductos muy íntimos de las subjetividades y los cuerpos. La divulgación de estas indagaciones tiene resultados importantes como el incremento de iniciativas institucionalizadas de exhibición que llevan, por ejemplo, a la muestra mexicana de fotografías Desde nosotras que, en la segunda edición (2020), expone imágenes "realizadas a lo largo de cuatro décadas por tres generaciones de mujeres" (Petrich 2020) y que tratan de la fuerza de la lucha social como de la expresión artística.

Con este marco de referencia, se exponen parte de los resultados de la investigación del cuerpo femenino representado en la fotografía que artistas mujeres latinoamericanas realizaron entre 2010 y 2020. Esta pesquisa busca comprender y modelizar, con recursos de la semiótica, cómo las creadoras contemporáneas representan parcial o totalmente el cuerpo femenil a través de la fotografía digital divulgada en medios virtuales, lo que correspondería a una estrategia para movilizar hacia acciones transformadoras de las lecturas y condiciones de la vida de actores sociales de un ámbito cultural con valores en conflicto. De la muestra tratada, y a modo de ejemplar del proceso relacionado con la fotografía documental y artística, se expone el análisis de la imagen sin título creada por la fotógrafa mexicana Victoria Razo.

\section{Proceso metodológico}

Durante la investigación fue realizado un rastreo en las redes sociales, páginas webs y documentos sobre el trabajo de las artistas contemporáneas para obtener una muestra de obras fotográficas que cumplan con el doble criterio de representar el cuerpo femenino en una construcción en contravía del discurso iconográfico heteronormativo y dentro de una búsqueda participativa y contra la censura dirigida a la mujer y la artista. Se encontró que, en el ámbito espacial de la investigación, América Latina, muchas creadoras visuales han adoptado progresivamente, en los últimos veinte años, la fotografía digital como recurso expresivo (Porras 2014, Rosenblum 2010), dada la capacidad etnográfica que posibilita la cámara, incluso la del teléfono celular, en diferentes y variados espacios de la vida cotidiana, comprendidos aquellos con limitaciones de iluminación y otras restricciones de acceso. Las cámaras con película, las de los móviles, las sin espejo, con modos manuales o digitales de operación, etc., ofrecen cierta potencialidad al ojo de la artista que entra discreta u ostentosamente en los escenarios de exploración de las relaciones sociales y de la intimidad para escribir con la luz una visión de lo que acontece y guarda como impronta de la experiencia.

Obtenida la muestra, constituida por diferentes archivos autorizados por las artistas como Sonia Carolina Madrigal Loyola y Tabata Roja (México), Ana Espinal (República Dominicana), Anelí Pupo Rodríguez (Cuba), Victoria Holguín y Juliana Ladrón de Guevara (Colombia), entre otras, se hizo la categorización de las fotografías, consideradas datos cualitativos de investigación interpretativa, con criterios como la representación del cuerpo en un plano general, partes de este en primer plano, el retrato o autorretrato, la puesta en escena de la corporeidad femenina en un escenario envolvente o en una composición horizontal o vertical. En todos 
los casos, se trata del cuerpo propio (de la fotógrafa) o de otras mujeres, mostrada con diferentes usos técnicos en una narrativa tomada de la vida cotidiana o de la ficción, pero con importantes efectos simbólicos. Los ejemplares analizados responden también a una puesta en circulación de la imagen en medios virtuales, muchos relacionados con el examen político, social y afectivo del ser y estar en corporeidad de mujer. El estudio de cada fotografía partió de un enfoque que la semiótica denomina inmanente-textual y que trata específicamente de la organización interna del constructo visual. Este procedimiento, que Polidoro (2016) retoma con el nombre de studium planteado por Barthes (1980) y Ricoeur (2002), busca comprender qué es y cómo funciona el objeto significante discretizado del entorno sociocultural de producción y de circulación. Con este análisis, se esclarecieron los principios y procedimientos de la elaboración del enunciado fotográfico con figuras, ámbitos narrativos y valores articulados con las elaboraciones expresivas.

Pero Fontanille (2016) ha replanteado el principio de inmanencia para restablecer que los límites de análisis del objeto de estudio, para la semiótica actual, no corresponden necesariamente a los límites del texto-enunciado, sino los que se configuran en la relación de este con otros conjuntos sígnicos en el curso de interacciones sociales, en que los actores son guiados en el hacer por estrategias amparadas en el ethos cultural. Además del examen detallado de la constitución del objeto (studium), se requiere la observación del comportamiento de este en las relaciones intersubjetivas, momento que Ricoeur $(2002,192)$ denominaría el punctum que completa el arco hermenéutico. Esta concepción de la aparición y correlación del trabajo expresivo en escenas de la vida sociocultural precisa mejor las relaciones del nebuloso criterio del contexto, que ahora es llevado a niveles de análisis precisos y correlativos.

El paso del análisis inmanente al punctum está determinado por el modo en que el texto-enunciado adquiere una presencia en escenas sociales a través de la materialidad que lo encarna y posibilita la circulación y uso, tal como un texto verbal se materializa en un libro digital, de impresión costosa o en una fotocopia que llega a las manos de los lectores. Precisamente, en esas escenas de exhibición e intercambio, se explora cómo el enunciado moviliza la sensibilidad y la comprensión sobre un acontecimiento que se ofrece a la mirada como experiencia representada y activadora del sentido. El studium y el punctum son tratados, por el método de análisis semiótico que organiza una jerarquía de los planos de inmanencia según la expresión de las prácticas semióticas (Fontanille 2016), con significativos desarrollos de Basso-Fossali (2011), Dondero (2014, 2016, 2020) y Beyaert-Geslin (2017) sobre la imagen fotográfica.

\section{Resultados del análisis de la fotografía documental del cuerpo femenino}

Para comprender cómo las artistas contemporáneas latinoamericanas representan el cuerpo femenino a través de la fotografía y emplean medios virtuales para hacer visible un discurso que apunta a la transformación de la realidad social, la fotografía sin título de la mexicana Victoria Razo fue tratada como un ejemplar o un tipo de representante (Fontanille 2001) que reúne muchos de los aspectos y de las características de la producción y puesta en circulación de la mayor parte de las fotografías de la muestra acopiada en la investigación. La fotógrafa hizo el registro visual en las marchas del Día Internacional de la Mujer, el 8 de marzo de 2020, en Ciudad de México, y la imagen está publicada en la página web y en el Instagram de Razo. Con todo, corresponde al género de fotografía documental o periodística que plasma una situación, intervengan seres humanos o no, sin afirmar que se trate de una exposición fiel y transparente del mundo registrado. Para Floch (1986), la complejidad de este tipo de imágenes, más allá de la convicción de que son documentos, radica en que no muestran la realidad como la verían diferentes espectadores si se encontraran en el mismo punto de vista y en el momento 


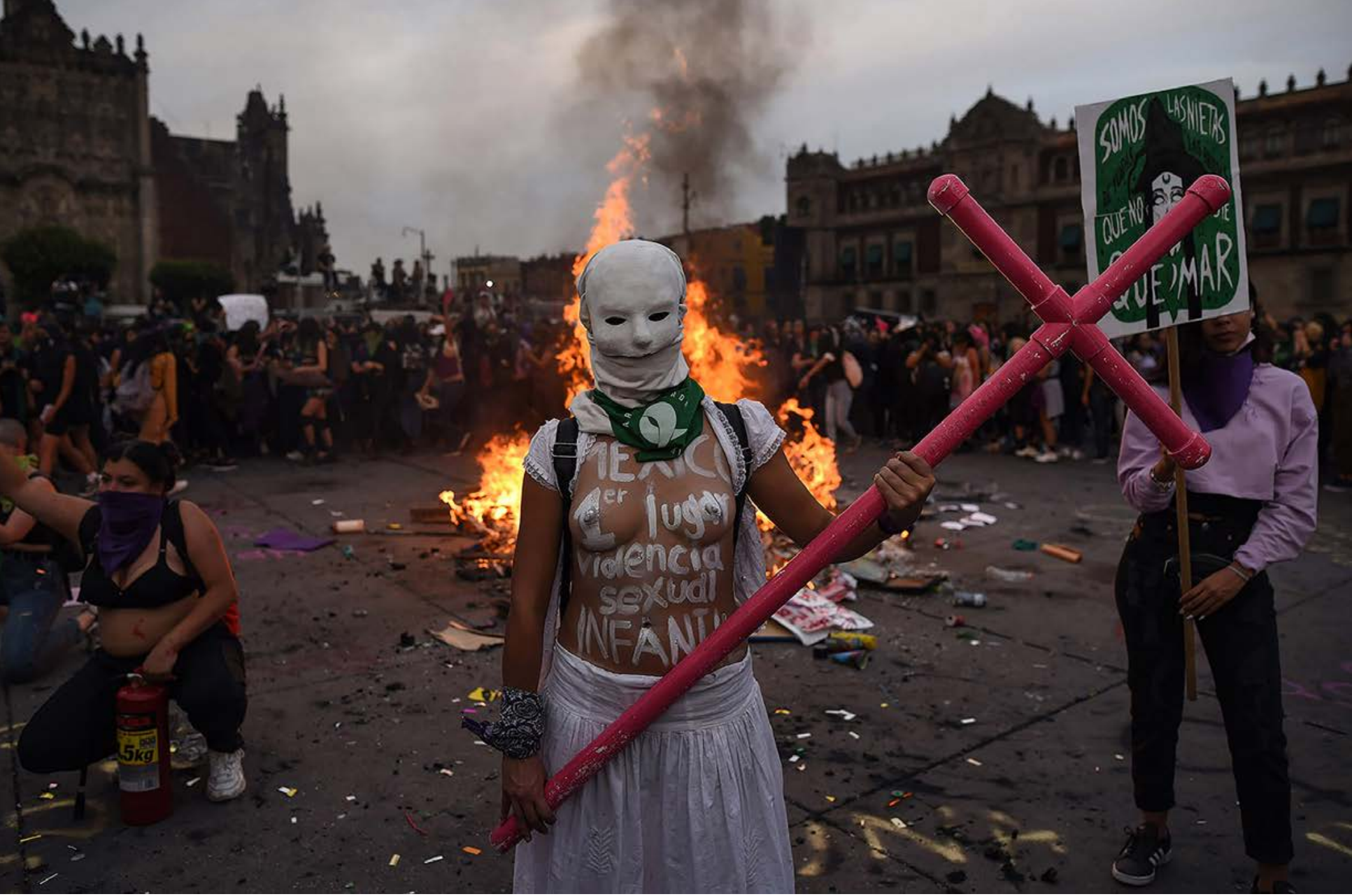

$\mathbf{v}$

V

Figura 1. Victoria Razo, Sin título. 2020. Fotografía digital, $7500 \times 5008$ ppp. Victoria Razo Photojournalist. México. Fuente: http://www. victoriarazo.com/ (consultado el 22 de mayo de 2020). exacto de la toma; por el contrario, las fotografías de este tipo llevan a ver cosas que de otra manera no se verían, a tomar posiciones que no se tomarían (Mangano 2015). Esta opacidad es una propiedad de todo objeto portador de significados e implica el trabajo de interpretación que siempre es imperfecto y abre nuevas posibilidades de comprensión, de construcción de narrativas y de conocimientos (Fontanille 2017, 136) (figura 1).

La fotografía documental parece salir airosa de una discusión sobre la veridicción que ella hace del mundo. Pero, por opacidad representacional, pone en juego juzgamientos epistémicos que relacionan la textualidad fotográfica y las prácticas de producción y recepción que le son conexas (Dondero 2021), abordables desde las configuraciones plásticas y figurativas, la coherencia interna de la imagen y la significación, que depende de prácticas productivas (Beyaert-Geslin 2006) y de los dispositivos de representación y divulgación de cada fotografía según el estatuto documental, científico, publicitario, etc., de ella. En la fotografía de Razo, existe así la escena contenida en la imagen, que la fotógrafa eligió y capturó de actos in situ, y la escena de circulación de la obra.

\section{Studium de la fotografía}

Barthes (1970) llamó trucaje al procedimiento de connotación en que el fotógrafo aprovecha el estatuto de credibilidad de la imagen documental e interviene para expresar un mensaje evidente, pero con alcances de sentido más allá de lo figurado. Así, el modo de captar manipula al observador con los efectos de la organización del enunciado para hacerlo mirar determinadas cosas. El análisis objetivado de la fotografía incluye la técnica de registro del signo porque desde ahí se organiza la sintaxis de los elementos integrados y se establecen 


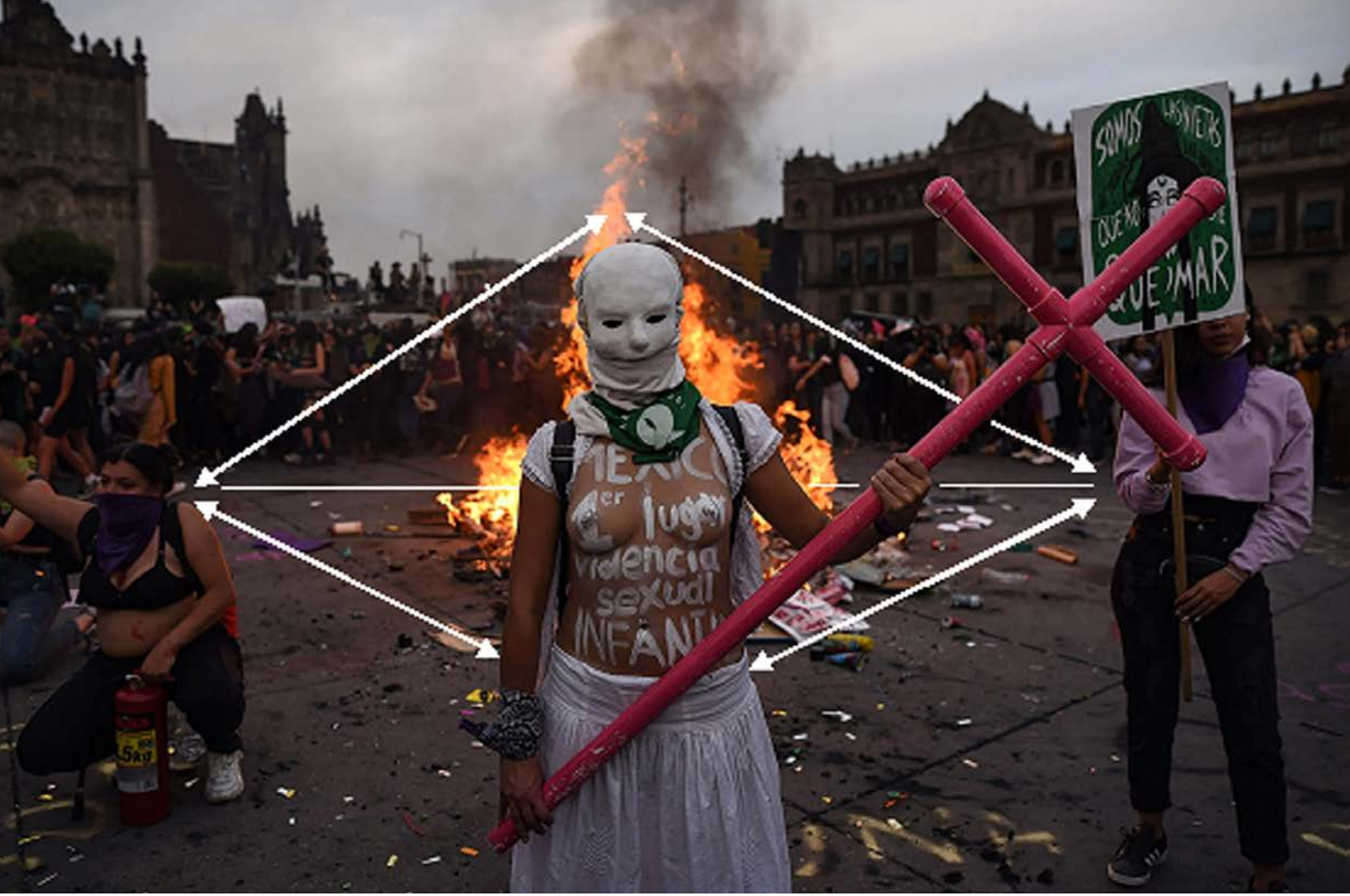

$\mathbf{v}$

$\mathbf{V}$

Figura 3. Identificación de ortocentros de los triángulos que integran el rombo central y composicional en la fotografía de V. Razo. distinguen edificaciones coloniales de Ciudad de México. Las líneas diagonales, proyectadas desde las esquinas del rectángulo fotográfico, convergen en el centro del pecho de la mujer de blanco, justo donde está escrita la palabra "México", parcialmente cubierta por el pañuelo en el cuello (figura 3).

La correlación entre cuerpos y arquitectura se puede esquematizar en un rombo que junta dos triángulos, uno definido por las mujeres a los lados, de pie y en cuclillas (en el esquema de la figura 4 representadas por los puntos verdes), y el ortocentro ocupado por la mujer con la máscara blanca. El otro triángulo está constituido, igualmente, por las dos mujeres a los lados, pero el ortocentro es el fuego que coincide detrás de la mujer con la falda blanca. Para hacer coincidir los dos ortocentros, la fotógrafa hizo un desplazamiento en el espacio, lo que produce una distorsión en el gran círculo de mujeres alrededor del fuego que en la imagen parece un arco o herradura que parte de la mujer de cuclillas y se extiende detrás de la fogata y de la mujer con el cartel verde. Así, en el plano o perímetro cuadrado de la plaza colonial de la ciudad, heredado del urbanismo romano y español, está un gran círculo ritual, construido por las mujeres, y dentro está el rombo construido por dos figuras triangulares, agudas y dramáticas, demarcadas por cuerpos femeninos; este rombo está redireccionado para hacer encontrar una de las puntas con la mirada del espectador y el lugar central de la margen ocupado por la mujer del centro; detrás de esta, el fuego se erige como una especie de aura. El primer triángulo interpela al observador y dinamiza las sensaciones de equilibrio y desequilibrio del conjunto.

Los diferentes formantes plásticos (líneas, puntos, playas cromáticas e intensidades lumínicas) distribuidos en los planos conforman la narrativa visual y pueden leerse en relación con parámetros culturales. El antifaz de la mujer con falda cubre el rostro hasta la nariz, mientras que la boca está cubierta por un pañuelo blanco y en el cuello va uno verde que se relaciona en las marchas feministas con la legalización del aborto. Además, ella porta entre las manos una cruz rosada que asciende en diagonal hacia la izquierda, símbolo que se relaciona con los actos 


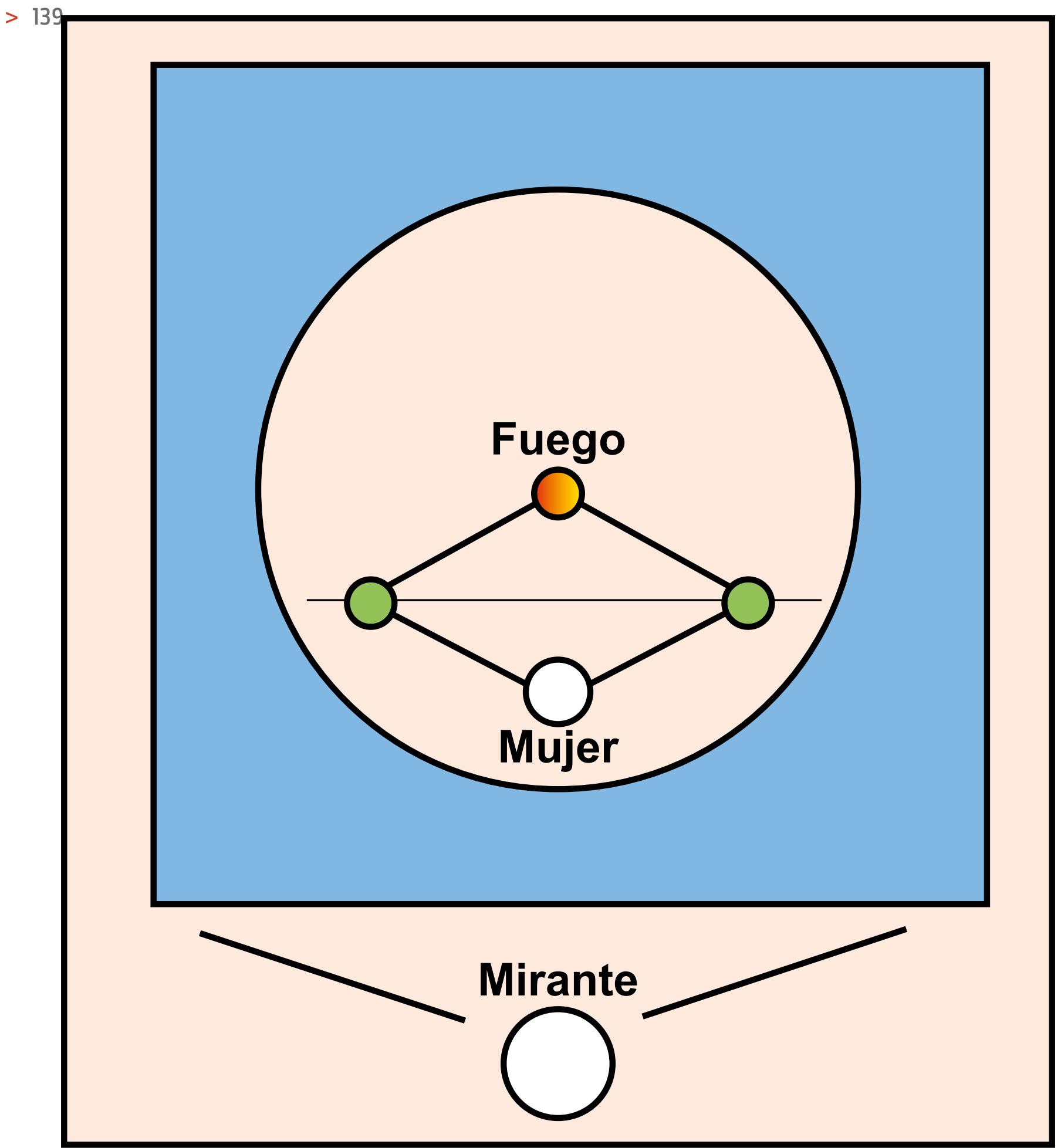

sacrificiales del cristianismo; pero el rosado, color arquetípico de lo femenino en Occidente, establece una estrategia retórico-visual que desplaza la centralidad del sexo masculino hacia la situación sacrificial de la madre. El pecho desnudo de la figura central modaliza al observador para que mire las mamas que socialmente se han erotizado hasta convertirlas en tabú, incluso el acto de amamantar, pero que en la imagen parece aludir a la alimentación materna de los hijos violentados y a la idea ancestral del poder maternal que da el ser y lo nutre (Revilla 2012). La imagen de Razo no copia la realidad, la connota y, para esto, la artista se esmera en apropiarse de los cuerpos presentes en la manifestación pública para crear una composición visual coherente y creíble. 
La mujer de blanco en la fotografía asemeja una figura tribal, una sacerdotisa, santera o santa que irradia un aura incandescente por efecto de la hoguera. El hecho de que ella, la cruz y las llamas ocupen el centro del círculo recuerda ceremonias rituales, fuera de las convenciones sociales, y a procesos sacrificiales, como el de Juana de Arco o de muchas condenadas al suplicio. Pero, en la fotografía, esta figura y quienes la acompañan muestran otra inmolación que también recae sobre ellas como genitoras. El mensaje escrito en el centro del pecho expresa "México", en caracteres blancos y mayúsculas sostenidas. La expresión "1.er lugar", en minúsculas, está escrito sobre el volumen de los senos. Sobre el vientre, precisamente encima de la zona corporal de los procesos de gestación y parto, en el área de concentración nervioso-visceral del organismo, termina el enunciado verbal con "violencia sexual infantil", y esta última palabra, más cerca del pubis, está en mayúsculas sostenidas. Este texto refiere a los informes, como el de la Organización para la Cooperación y el Desarrollo Económico (OCDE), que declararon a México, en 2019, como el país con mayores casos de violencia sexual infantil, con 5,4 millones de casos reportados anualmente (Senado de la República de México 2019). Esta violencia sexual, en el hogar, perpetrada por familiares cercanos a las víctimas, está presente también en los señuelos de las redes sociales, la pornografía infantil, la trata de personas, etc. La mujer aparece ante los ojos del espectador de la fotografía como una punta de lanza, como una deidad o vestal que denuncia, en medio de la blancura de las víctimas, el horror impuesto a los infantes y que consume a las progenitoras que padecen esta inhumanidad.

En escena, están otros pañuelos, carteles, vestimentas, gestos y emblemas que pertenecen a una codificación reconocida entre las personas que protestan. Una mujer lleva la pancarta en la que se distingue a una bruja con sombrero negro sobre un fondo verde y el mensaje "somos las nietas de todas las brujas que nunca pudieron quemar"; esta es una consigna que las feministas cantan en las marchas para recordar a congéneres, como las parteras, curanderas, opositoras políticas, científicas, artistas e inspiradoras de movimientos sociales perseguidas y arrasadas por instituciones, como la Iglesia católica, que las consideraban una amenaza para la sociedad (Norandi 2008). Además, la luz obra como un configurador del tiempo y de tensiones entre lo visible e invisible, lo que afecta cómo el observador accede a la información de la imagen. El cielo gris, el modo de distribución de la luz ambiental y las intensidades lumínicas de la fogata perfilan los cuerpos de las mujeres y los elementos que portan, al tiempo que la pérdida de fuerza luminosa coincide con la distorsión de la imagen por la profundidad de campo. La correlación entre los cuerpos que luchan por derechos y contra la violencia ejercida sobre la infancia se caracteriza por un juego que oscila entre el mostrar (el hacer ver) la denuncia y el hacer transformador reclamado sobre el objeto de la protesta, al mismo tiempo que lo narrado oculta (impide el acceso de la visión del mirante) ciertos aspectos de la identidad personal de las protagonistas de la marcha.

Esta configuración visual no está libre de conflictos interpretativos que se basan en los puntos de vista o los lugares desde los cuales se ofrece la visión de las cosas, como expresa Fontanille (1989), quien demuestra que en la interacción entre observador e imagen puede emerger una confabulación entre las instancias enunciativas (el enunciador y el enunciatario) cuando el signo visual expone lo representado de tal modo que no es posible dejar de observar todo lo que hace saber. En oposición, la imagen inaccesible lleva al antagonismo cognitivo, entre enunciador y enunciatario, jugado por el ocultamiento (con sombras, velos, distorsiones) del contenido que no se puede observar ni conocer certeramente. En contradicción con la exposición propia de la confabulación, la imagen puede suscitar discordia entre enunciador, enunciado y observador cuando algo obstruye parcialmente el contenido visual que no se puede apreciar totalmente y la imagen no permite construir cómodamente un saber. En refutación de la inaccesibilidad, está la conciliación, en que el contenido es accesible, observable, pero con algunos matices u ocultamientos que no permiten saber plenamente la información que posee. La fotografía de Razo, entre estas accesibilidades cognitivas (representadas en la figura 5), se ubica en la conciliación, puesto que la imagen, más que confabular con el observador, oscila entre una exposición de la marcha de mujeres y de los motivos de esta movilización, 


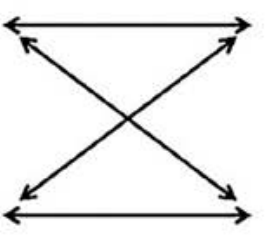

El mirante no puede observar, La imagen hace no saber ANTAGONISMO

$\begin{array}{r}\text { ACCESIBILIDAD } \\ \text { El mirante puede observar, } \\ \text { la imagen no hacer no saber } \\ \hline \text { CONCILIACIÓN }\end{array}$

\section{OBSTRUCCIÓN}

El mirante no puede no observar, la imagen no hacer saber

DISCORDIA

pero construye parcialmente la información, dado que se impide el acceso a la identidad de las que tienen el rostro cubierto y de las que se desdibujan entre la masa de manifestantes. La estrategia enunciativa de esta imagen, esquemáticamente, hace posible observar lo esencial (el actante colectivo de las indignadas, lo que hacen y la causa), pero inhibe el acceso a la identidad personal de las que son objeto recurrente de persecuciones.

Este tipo de análisis semiótico de la imagen como resultado de un acto de enunciación demuestra que lo visual está articulado como un verdadero lenguaje con capacidad de reflexionar sobre sí mismo o de constituirse en un metalenguaje. Esto permite prever la manera en que el observador debe asumir la significación por el modo en que la imagen está sometida a constreñimientos del lenguaje visual, de suerte que el enunciador y el enunciatario se constituyen recíprocamente en el anclaje del enunciado para la construcción del sentido (Dondero 2014). Otros casos de la muestra investigada demuestran que el retrato y el autorretrato están sometidos a procesos similares cuando reconstruyen la presencia del invisibilizado, estigmatizado y negado o del cuerpo fluctuante entre una identidad impuesta y una identidad auténtica.

Los retratos con hechura vertical cuentan con un espacio ocupado por el cuerpo en tensión con el fondo y el observador enfoca la atención en el retratado, sin desviación causada por otros elementos. En esta decisión compositiva, como en Ni santa ni puta (figura 6), de Juliana Ladrón de Guevara, la verticalidad hace que la desnudez del cuerpo tatuado se ostente con seguridad natural y sostenga los ojos bien abiertos ante el mirante confrontado por una feminidad con estética punk. La fotógrafa realiza trabajos con imágenes fijas y documentales sobre los movimientos afrofeministas en Colombia y recupera las experiencias de las mujeres reincorporadas a la vida civil después de abandonar las armas del conflicto colombiano; con la imagen fija, muestra cuerpos semidesnudos, en blanco y negro, para divulgar el modo de ser en cuerpo de mujer o de hombre.

Otro registro vertical es el Autorretrato, de Tabata Rojas (figura 7), artista preocupada por la construcción de la propia identidad con el reconocimiento de la corporalidad desnuda y dispuesta como recurso narrativo. La imagen registra, en un plano entero y con desenfoque de los objetos y del espacio, el cuerpo de la fotógrafa. La mirada se escinde en un ojo que observa lo que capta la cámara fotográfica con que ella se retrata y otro que mira el lugar de ella en el espejo, que es también el punto de vista del observador de la fotografía. En un juego de miradas y juzgamientos recíprocos, la mujer sigue el trabajo de reconocerse y produce un sincretismo entre la mujer que se enuncia y el observador que atestigua ese acto de mostrarse por sí misma.
Figura 5. La conciliación como modo estratégico de acceso cognitivo en la fotografía de Razo a partir del modelo de Fontanille (1989). 
Figura 6. Juliana Ladrón de Guevara, Ni santa ni 015. Fotografía digital, $3840 \times 5760 \mathrm{ppp}$

(Bogotá: La Valija de Fuego).

Disponible en https://

www.domestika.org/en/

projects/545795-body-paint-

libro-mi-campo-de-batalla-

de-juliana-ladron-de-guevara

(consultado el 12 de abril
de 2020).

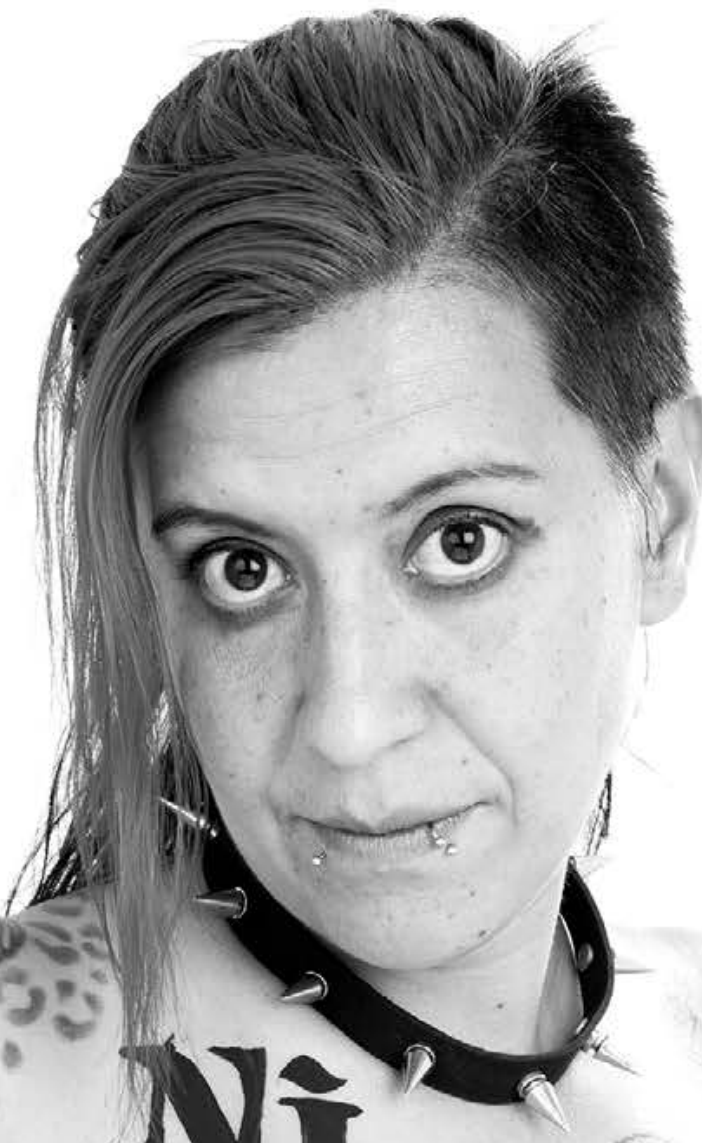


Figura 7. Tabata Roja, Autorretrato. 2019. Fotografía análoga

convertida a formato digital, 1108

$\times 1551 \mathrm{ppp}$. Buenos Aires.

Fuente: https://www facebook.

com/tabata.roja. 16 (consultado 2

de mayo de 2020).

* 


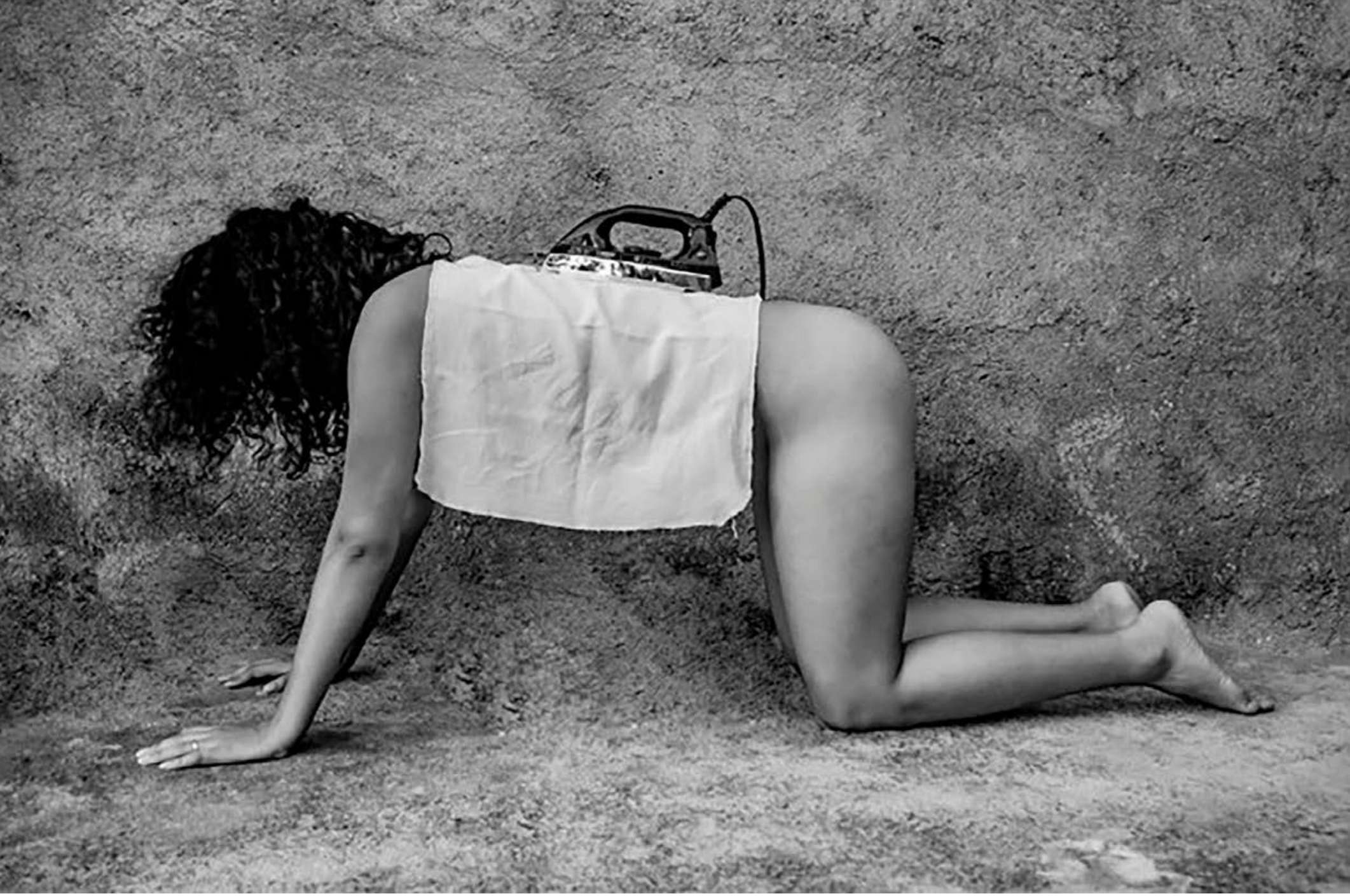

$\mathbf{v}$

V

Figura 8. Anelí Pupo Rodríguez, Tierno cilicio. 2020. Fotografía digital, $700 \times 466$ ppp. De la serie Tiranía de la tradición, Ybor Art Factory, Tampa Estados Unidos. Fuente: https:// www.youtube.com/ watch?v=b7mYe58_nY4 (consultado 12 de junio de 2020).
La orientación horizontal del retrato incluye el simulacro de un mayor espacio en la escena representada, con la posibilidad de integrar variados elementos en la topología composicional, cuyo centro queda más directamente afectado por el fondo (Groupe $\mu$ 1993), de modo que el observador se involucra más en la atmósfera del mundo que rodea lo central, como sucede con la fotografía de Razo y en la puesta en escena de Tierno cilicio, obra de Anelí Pupo Rodríguez (figura 8). El cuerpo femenino, en posición de coitus more ferarum (coito a la manera de los animales) está solo, en un espacio árido; ella, con argolla matrimonial, carga del yugo de las obligaciones hogareñas como algo incorporado disciplinariamente y se muestra como una mesa de planchar, sexualmente disponible, al tiempo que carece de identidad por causa del ocultamiento del rostro, la desnudez mostrada parcialmente por la postura y el pañuelo irónicamente impoluto. En esta domesticidad indignante, el enunciatario no puede mirar todo de esta "mujer de alguien" que aparece en plano cerrado. De este modo, Pupo explora con la cámara los espacios cercados y cotidianos de la vida cubana y retrata el sometimiento para provocar la conmoción de quien observa.

En los retratos de composición vertical analizados, los cuerpos están dispuestos voluntariamente para ser vistos e interrogar al mirante potencial, con quien se construye una confabulación en la que es imposible no ver lo que los cuerpos de mujeres expresan. En las imágenes horizontales, sucede una conciliación cognitiva, pues, más que confabular, se expone un problema humano al tiempo que se ocultan algunos aspectos relacionados con la identidad particular del retratado, porque, en el ámbito del querer decir, es más relevante el conflicto narrado. Lo mostrado no interesa como un caso aislado particular, con nombre propio de persona afectada o militante, sino como una elaboración simbólica que representa una experiencia generalizada en la cultura y que requiere de urgentes respuestas. En este confabular entre las instancias enunciativas, no es posible no observar lo que cada imagen hace saber (Fontanille 1989), para restituir al cuerpo femenino una subjetividad inalienable y crítica; en esto, radica la fuerza del enunciado artístico-visual que protesta. 


\section{Punctumo la fotografía como constituyente de escenas intersubjetivas}

Si las prácticas semióticas son la acción en curso, las fotografías, al circular en los medios virtuales, se interrelacionan con un mundo de experiencias de actores sociales y son sometidas a condicionamientos y adaptaciones de sentido, en que se negocian las dificultades y los azares interpretativos que son parte de los modos de existir y persistir en la vida de los seres humanos (Fontanille 2017). El procedimiento de exposición en medios virtuales de la imagen fotográfica del cuerpo femenino establece las condiciones de interacción de ella con los observadores del ciberespacio, quienes interpretan, comentan, aceptan, se apropian o rechazan la obra condicionados por las propias circunstancias de vida y lectura. Este punctum en la construcción del arco interpretativo del conjunto significante se soporta en regímenes de interacción social, como la respuesta que produce el usuario en una acción programada, en una situación de manipulación, en el seno de las empatías o de los ajustes intersubjetivos o en escenarios azarosos o accidentales en los que no se puede prever la responsabilidad directa del alguien específico (Landowski 2016). Sea cual fuere el régimen de interacción (programación, manipulación, ajuste, accidente) que emerja entre los actores y objetos significantes, se trata de producciones de sentido que responden a estilos estratégicos, valores, maniobras cognitivas, sensibilidades y afectividades que se pueden entender como consecuencias de los enunciados elaborados con los lenguajes de la vida cultural y de los constituyentes de identidades culturales (Fontanille 2017, 26) que remiten, todos, a una ética y estética particulares.

Estos regímenes hacen parte de la escena práctica, que es una situación semiótica heterogénea que reúne los elementos necesarios para la producción e interpretación que surge en una interacción comunicativa (Fontanille 2016, 25). Para comprender el texto delimitado de la fotografía, es necesaria la descripción de este, pero es importante analizar cómo resulta de una necesidad de escritura en el mundo y cómo la lectura de la impronta resultante está determinada por la situación de producción y de intercambio intersubjetivo. No se trata del nebuloso contexto, más o menos explicativo del texto, que reduce el objeto de análisis solo a la textualidad o a factores externos como el único nivel de examen pertinente. Las escenas de las prácticas se caracterizan por tener el carácter de un proceso abierto, circunscrito en una escena de intercambio que responde a parámetros y expectativas culturales, aun cuando se trata de describirlas y cuestionarlas. Así, para que alguien perciba y produzca juicios frente a una imagen, este constructo debe pasar por una serie de codificaciones y conversiones en las interfaces, como las electrónicas, que la convierten en información material que se distribuye, preserva y se hace legible para el humano que interactúa ella en una circunstancia específica.

La fotografía de Razo tiene una escena de producción, que es la marcha de mujeres en Ciudad de México, una conversión en registro digital accesible que, como organización significante, presentifica el acontecimiento pasado en una nueva escena interpretativa, construida con los portales en que aparece la imagen, condicionada por decisiones estratégicas de los propietarios y diseñadores de la página web, los intereses y las ocupaciones de la fotógrafa, las empresas de noticias, las actuaciones proporcionales a las competencias de los observadores, etc. La existencia material de la fotografía digital narra, para observadores usualmente preseleccionados por los ámbitos estratégicos de divulgación de las páginas contenedoras, algo acontecido en otro espacio y tiempo; en esta praxis, en el origen y en la fruición interpretativa, se reconocen cuerpos figurados que interpelan a otros y el sentido emergerá, en acto, de la confrontación misma de coparticipantes" (Landowski 2015, 107). 
La fotografía de Razo apareció en diversos medios internacionales, en especial europeos, que informaron de la violencia contra las mujeres durante la marcha; la imagen tuvo valoraciones de diversa índole, como el señalamiento de ser parte y producto de la alienación feminista, de traición a la patria, de poetización cínica de los problemas sociales, pero también fue reconocida como gesto revolucionario que une el arte fotográfico y la lucha por la dignidad humana. Le Parisien, el 9 de marzo de 2020, publicó y acreditó la fotógrafa como parte de la Agence France-Presse (AFP), mientras que el medio digital polaco Noizz publicó el mismo registro con mención de Getty Images como fuente, lo que deja entrever que para la escenificación de la obra se realizaron procesos contractuales con proveedores de recursos para las agencias noticiosas. La imagen hizo parte de la serie de fotografías publicadas por la autora en Instagram, bajo la rúbrica "Miles de mujeres marcharon durante el Día Internacional de la Mujer en la Ciudad de México, México, 8 de marzo de 2020, en medio de una crisis de feminicidios que se registran en todo el país". Actualmente la imagen no aparece en el espacio personal de la fotoperiodista, $h t t p: / / w w w$.victoriarazo.com, donde fue substituida, en la lógica de las publicaciones en el ciberespacio, por imágenes de la marcha de 2021; sin embargo, el objeto hace parte de una serie de escenas prácticas en las que fue asumida por diferentes regímenes de creencia convergentes o en conflicto.

El observador comprometido no interpreta a la deriva y trata de establecer y articular las intencionalidades de los objetos significantes y de los escenarios en que aparecen. La fotografía de Razo reúne coyunturalmente comprensiones relacionadas con el modo de manifestar la información periodística, la lucha reivindicadora femenina, la divulgación personal de los trabajos de la fotógrafa, el estatuto social de la fotografía callejera, testimonial y artística, y los modos de composición que autorizan la calidad mínima para la circulación de la imagen, etc. La lectura preocupada y convocada por esta imagen corresponde a las construcciones discursivas sobre coyunturas sociales, de aspecto rizomático y que son nodos del hacer persuasivo de la cultura ante los actores que la dinamizan. El régimen de creencia aparece como el conjunto de elementos sensoriales, afectivos, sociales y cognitivos con los que alguien confronta lo que proponen el objeto de interpretación y las experiencias acumuladas en la memoria (Fontanille 2017, 170). Quien participa en esta confrontación responde también a estrategias de orden sociocultural o a esquemas de acción, más o menos consolidados, con los que se construyen las expectativas frente a las escenas y se hacen los acomodos comprensivos, de lo que resulta que el objeto y los actores implicados correlacionan otras prácticas concomitantes (Fontanille 2016, 28), tal vez no previstas, o realicen comprensiones que surgen de la correspondencia entre diferentes sensibilidades, modos de percepción e intelección social.

Algunos elementos que materializan los regímenes de creencia en la fotografía de Razo son la figura de la cruz rosada que sostiene la mujer y que remite a formas de vida específicas (Fontanille, 2017) condicionadas por la fe o la duda; la alteración de la codificación cromática de este símbolo y la reinterpretación de la bruja se relacionan con figuras míticas en las que confluyen fuerzas contradictorias en el cuerpo femenino, como lo sagrado y lo profano. Aunque en la imagen se espera la centralidad de los derechos de las mujeres, hay un movimiento que recentra la atención en los órganos diferenciales femeninos de una especie de diosa gestante, sobre la que se emplea la escritura del lenguaje verbal con un tratamiento iconografemático (Rosales 2012) para subrayar la intencionalidad de la fotografía alrededor de la violencia sexual sobre la infancia. Esta convergencia/divergencia de expectativas frente al género discursivo y la tipología textual de la fotografía, pese al aspecto clásico de la composición, pone a la par la denuncia, la gestualidad creativa, el feminismo y el fotoperiodismo. Así, la obra se integra a un movimiento agitador que interpela los modos de exhibición del cuerpo de la mujer, relata la lucha intrincada de amordazados y ostenta unas presencias que hibridan parámetros socioculturales para cuestionarlos. Este encabalgamiento de creencias expone cómo se provoca la acomodación estratégica del observador común, de los críticos de arte, intelectuales, políticos, activistas, etc., cuyas 
decisiones ante la obra se soportan en reglas e indicaciones para reconocer o marginar ámbitos categoriales de comprensión, para optar o no por ciertos imaginarios y para llegar a una disposición interior que permita aceptar la promesa y adoptar el régimen de creencia sugeridos por el texto (Fontanille 2017, 171).

Al ser publicada en redes de información del ciberespacio, la obra queda anclada a mensajes verbales, de diseño gráfico, etc., que remiten a intereses y posturas de un sujeto, eufórico o disfórico, con un estilo de vida que se "caracteriza por los comportamientos, las producciones simbólicas y los modos de interacción social" (Fontanille 2017, 305). El lector crítico puede concluir, frente a la fotografía analizada, que esta despliega fuera de sí una representación de una forma de vida cultural, de violencia y resistencia, al tiempo que la condensa en la figura de la mujer como centro del mito sacrificial, en la posición antropológica del héroe convertido en chivo expiatorio. Esto equivale a un gesto bello (beau geste, en francés) o a un constructo en tensión con las convenciones conceptuales y formales porque hibrida la artisticidad composicional, cromática, teatral y simbólica con el documento-impronta del mundo como deviene. La mujer en el centro de la imagen asume orgullosamente la diferencia fisiológica y gestante por la que es sometida; la exhibe porque acepta la condición de deidad sincretizada con la sacerdotisa, la loca, la bruja y la desquiciada que mira sabiamente sobre el fondo de la hoguera que ahora está para conjurar la infamia. En medio de esta beligerancia, está obligada al ocultamiento de la identidad propia para mantenerse en vida y con voz. La narrativa de la imagen denuncia cómo las mujeres son convertidas en víctimas por partida doble, porque reciben daño sobre lo que son, empezando por el propio cuerpo vivo, y porque también son violentados los seres que engendran para dar continuidad a la especie.

\section{Conclusiones}

Todo el análisis precedente es un caso concreto de registro artístico de experiencias cotidianas de protesta, de lucha y reivindicación social y cultural femenina que interpelan a un ethos y a los valores aceptados en la forma de vida. La toma fotográfica investigada y analizada hace parte de una muestra más compleja de obras de artistas latinoamericanas y de un movimiento social que se concreta en bienes culturales que articulan la organización del significado con las variaciones de este en las circunstancias críticas de uso e interpretación. En la ambición transformadora de la realidad circundante, las artistas se valen del cuerpo de mujer como clave en la lucha de recuperación del poder sobre sí mismas y sus propias imágenes (Muñoz-Muñoz y González-Moreno 2016, 84) y componen un gesto que defiende la dignidad inalienable. Los conjuntos significantes resultantes, como el registro del cuerpo-sujeto que se rebela, abren un devenir del sentido (diverso y divergente) que no es propuesto por un sujeto patémico, arrebatado o rabioso, que impone el propio deseo a los demás, sino que expresa un modo de percibir y conocer que aborda las implicaciones éticas del ejercicio del poder.

Esta lucha oscila entre la escena real y la reconstruida artísticamente por la fotografía; ante el magma de las posibles interpretaciones que esta suscita, es posible establecer, con rigor analítico, la pertinencia de unas lecturas en las que el observador capta determinadas cosas que lo llevan a cuestionarse, a criticar y a hacer ajustes, por empatía comprensiva, con los actores sociales retratados y los que se lanzan a la manifestación pública. Este tipo de capturas de protesta hace coincidir la sintaxis de la acción social, la memoria documentada, el gesto bello del arte y las hibridaciones de discursos en los que se integra el fotoperiodismo. Las fotografías analizadas son testimonio de cómo la gente resiste ante la ferocidad de las marginaciones y reificaciones; pero, al ser visibles en cualquier lugar del mundo, por la mediación digital en el ciberespacio, se integran en una estrategia de divulgación que dinamiza la resistencia y la protesta más allá del aquí y ahora y crea comunidades semejantes a las redes sociales lingüísticas. 
Entre los muchos elementos artísticos de la captura visual, se recupera, pese al anonimato de los sujetos fotografiados, la fuerza de la humanidad que poseen. La pintura del rostro de un desconocido (tronie), desarrollada por el barroco flamenco, insistía en el carácter del modelo humano que daba al artista la oportunidad de demostrar el propio virtuosismo creativo mientras hacía trascender la vitalidad del retratado. Este esmero dejó profundas huellas en el retrato fotográfico y en la fotografía documental, en los que sucede una exploración de la intrincada condición humana en el maremágnum de las contingencias. Pero las mujeres en la fotografía de Razo y de otras creadoras latinoamericanas no se satisfacen con reiterar los recursos disponibles en la historia del arte y proponen usos y lecturas sobre la identidad, reivindicada y reivindicadora, del sujeto que resiste a la sumisión de sí y de los congéneres.

Si para algunos es aceptable la afirmación de que el arte no transforma inmediatamente la realidad, sí se propone, desde él, como en las fotografías consideradas, alternativas de interpretación que abren la posibilidad del cambio, dado que las representaciones del mundo conducen a la toma de decisiones y a las acciones que movilizan la vida cultural. Los enunciados visuales que capturan a seres humanos que protestan exponen cuerpos sensibles, afectivos y cognitivos en una praxis social que contrapone lógicas y creencias culturales; provocan un mirar que no legitima solo el discurso feminista, sino que llama a la solidaridad sin miedo (Sandel 2020) entre las personas que la tradición y la globalización han relegado a un segundo lugar y que acumulan, además, sobrados argumentos y sensibilidades contra los regímenes de creencia, poderosos y persuasivos, de reificación y marginación de los seres humanos. 
[REFERENCIAS]

Alario Trigueros, María Teresa. 2008. Arte y feminismo. San Sebastián: Nerea.

Allochis, Leandro. 2017. El cuerpo simbólico: Representación y cuerpo contemporáneo. Buenos Aires: La Stampa.

Alonso, Rodrigo. 2017. "Cuerpo y arte: Tu cuerpo es un campo de batalla". En El cuerpo simbólico. Buenos Aires: La Stampa.

Antivilo, Julia. 2013. “Arte feminista latinoamericano: Rupturas de un arte político en la producción visual". Tesis de doctorado. Universidad de Chile. https://repositorio.uchile.cl/handle/2250/114336.

Ballester, Irene. 2017. “Cuerpos disidentes: Cuerpos en resistencia desde el arte y el feminismo". Rupturas 7, n. ${ }^{0}$ 2: 145-161. http://dx.doi. org/10.22458/rr.v7i2.1835.

Barthes, Roland. 1970. El mensaje fotográfico. Buenos Aires: Comunicaciones.

Barthes, Roland. 1980. La chambre claire. París: Seuil.

Báscones Reina, Noeli. 2018. "Mujer, autorretrato y discurso autobiográfico: Revisión del autorretrato fotográfico en la obra de mujeres artistas". Área Abierta: Revista de Comunicación Audiovisual y Publicitaria 18, n. ${ }^{0}$ 1: 111-130. http://dx.doi.org/10.5209/ARAB.57048.

Bautista Santos, Sandra Patricia. 2018. Poéticas de acción y reacción del género femenino en el arte colombiano desde 1980 hasta nuestros días. Sevilla: EnredArs.

Basso Fossali, Pierluigi y Maria Giulia Dondero. 2011. Sémiotique de la photographie. Limoges: Pulim.

Basso Fossali, Pierluigi y Maria Giulia Dondero. 2013. "Les temporalités de la photographie de mode". Infra-mince 8: 86-95.

Berger, John. 2016. Modos de ver. Barcelona: Gustavo Gilli.

Beyaert-Geslin, Anne. 2006. "L'image ressassé: Photo de presse et photo d'art". Comunication et langages 147: 119-135. https://www.persee. fr/doc/colan_0336-1500_2006_num_147_1_4584.

Beyaert-Geslin, Anne. 2017. Sémiotique du portrait: De Dibutade au selfie. Lovaina la Nueva: De Boeck Supérieur.

Campo Castro, Natalia. 2017. "Fotografía y enfoques de género: Aproximaciones teóricas para construir miradas de mujeres". La Manzana de la Discordia 12, n. ${ }^{0}$ 2: 7-21. https://bibliotecadigital. univalle.edu.co/handle/10893/11900?locale-attribute=es.

Cely Álvarez, Adriana María. 2015. “Cuerpos visualizados, subjetividades controladas: Discurso verbovisual sobre el cuerpo la tecnología en la publicidad de cosméticos". Tesis de doctorado. Universidad Complutense de Madrid. https://eprints.ucm.es/id/eprint/34416/.

Clemente-Fernández, María Dolores, Nieves Febrer-Fernández y María del Mar Martínez-Oña. 2018. "La fotografía documental como recurso en la obra de mujeres artistas: De la flâneuse a la crónica de realidades inventadas". Área Abierta 18, n. ${ }^{0}$ 1: 75-96. https://doi.org/10.5209/ ARAB.56602.

Cuesta Flórez, Alexa. 2012. “Feminismo, género o reivindicación en el arte del Caribe Colombiano". Revista Brasileira do Caribe 12, n. ${ }^{\circ} 24:$ 425457. https://www.redalyc.org/articulo.oa?id=159123802006.
D’Angelo, Ana. 2010. "La experiencia de la corporalidad en imágenes". Tabula Rasa, n. ${ }^{0}$ 13: 235-251. https://revistas.unicolmayor.edu. co/index.php/tabularasa/article/view/1431

Dondero, Maria Giulia. 2014. “ Les aventures du corps et de l'identité dans la photographie de mode". Actes Sémiotiques, n. ${ }^{0} 117$. https://www.unilim.fr/actes-semiotiques/4979.

Dondero, Maria Giulia. 2016. "L'énonciation énoncée dans l'image". En L'énonciation aujourd'hui, un concept clé des sciences du langage. Editado por Marion Colas-Blaise, Gian Maria Tore y Laurent Perrin, 241-258. Limoges: Lambert Lucas. https://orbi. uliege.be/handle/2268/176921.

Dondero, Maria Giulia. 2020. Les langages de l'image: De la peinture aux Big Visual Data. París: Hermann.

Dondero, Maria Giulia. 2021. "Les temporalités véridictoires dans la photo de sport". Actes Sémiotiques. https://www.unilim.fr/ actes-semiotiques/3377.

Floch, Jean-Marie. 1986. Les formes de l'empreinte: Brandt, CartierBresson, Doisneau, Stieglitz, Strand. París: Périgueux Fanlac.

Fontanille, Jacques. 1989. Les espaces subjectifs: Introduction à la sémiotique de l'observateur (discours, peinture, cinéma). París: Hachette.

Fontanille, Jacques. 2001. Semiótica del discurso. Lima: Universidad de Lima.

Fontanille, Jacques. 2016. Prácticas semióticas. Lima: Universidad de Lima.

Fontanille, Jacques. 2017. Formas de vida. Lima: Universidad de Lima.

Fontanille, Jacques. 2018. Cuerpo y sentido. Lima: Universidad de Lima.

Gajewski, Camille. 2015. "A Brief History of Women in Art ". Khan Academy. https://www.khanacademy.org/partner-content/tate/ women-in-art/history-of-women-in-art/a/a-brief-history-ofwomen-in-art.

Giunta, Andrea. 2018. Feminismo y arte latinoamericano: Historias de artistas que emanciparon el cuerpo. Buenos Aires: Siglo XXI.

González-Moreno, María Barbaño. 2016. “Fotografía, mujer e identidad: Imágenes femeninas en la fotografía desde finales de los 60". Tesis de doctorado. Universidad de Granada.

Guerrilla Girls. 2020. The Art of Behaving Badly. San Francisco: Chronicle Books.

Halperin, Julia y Charlotte Burns. 2019. "Female Artists Represent Just 2 Percent of the Market. Here's Why-and How That Can Change". Arnet. https://news.artnet.com/ womens-place-in-the-art-world/female-artists-represent-just-2 percent-market-heres-can-change-1654954.

Landowski, Eric. 2015. Pasiones sin nombre. Lima: Universidad de Lima.

Landowski, Eric. 2016. Interacciones arriesgadas. Lima: Universidad de Lima. 
Le Parisien. 2020. "Un jour sans nous: Au Mexique, une grève des femmes pour dénoncer les féminicides". https://www.leparisien.fr/ societe/un-jour-sans-nous-au-mexique-une-greve-des-femmes-pourdenoncer-les-feminicides-09-03-2020-8275650.php.

Magaña Villaseñor, Luz del Carmen. 2014. “El feminismo dentro de la representación de la mujer en la historia del arte". El Artista, n. ${ }^{0}$ 11: 189-202. https://biblat.unam.mx/en/revista/el-artista/articulo/ el-feminismo-dentro-de-la-representacion-de-la-mujer-en-lahistoria-del-arte-una-mirada-a-los-antecedentes-de-los-diferentesestereotipos-del-cuerpo-femenino-dentro-de-la-obra-de-arte.

Mangano, Dario. 2015. "LOMO sapiens: De la photographie". Actes Sémiotiques 118. https://www.unilim.fr/actes-semiotiques/5384.

Márquez Guerrero, María. 2007. “Análisis semiótico del concepto actual de 'belleza' en la publicidad dirigida a la mujer". Trastorno de la Conducta Alimentaria, n. ${ }^{0}$ 5: 483-506. https://dialnet.unirioja.es/ servlet/articulo? codigo=2379938.

Martínez Cano, Silvia. 2014. "Las mujeres desde el marco: La doble visión de las mujeres en la imagen artística y la cultura visual". Dossier Feministes 18: 227-243. https://repositorio.comillas.edu/xmlui/ handle/11531/13323.

Marzal Felici, Javier. 2012. "Reflexiones en torno a la semiótica de la fotografía en la era digital". Conferencia pronunciada en Universidade da Coruña. https://ruc.udc.es/dspace/handle/2183/13442.

Muñoz-Muñoz, Ana María y María Barbaño González-Moreno. 2014. “La mujer como objeto (modelo) y sujeto (fotógrafa) en la fotografía". Arte, Individuo y Sociedad 26, n. ${ }^{0}$ 1: 39-54. https://doi.org/10.5209/ rev_ARIS.2014.v26.n1.40581.

Noizz. 2020. “Dzień Kobiet 2020: Te zdjęcia z protestów kobiet na świecie mówią same za siebie [galeria]". https://noizz.pl/spoleczenstwo/ dzien-kobiet-2020-zdjecia-z-protestow-na-calym-swiecie/z6ljcp5.

Norandi, Mariana. 2008. “Mito, las brujas de laEdadMedia: solo eran mujeres con conocimiento". La Jornada, 28 de febrero. https://www.jornada. com.mx/2008/02/28/index.php? section=ciencias\&article=a02n1cie.

O'Hagan, Sean. 2018. "What Next for Photography in the Age of Instagram?". The Guardian, 14 de octubre. https://www.theguardian. com/artanddesign/2018/oct/14/future-photography-in-the-age-ofinstagram-essay-sean-o-hagan.

Palazón, María Encarna. 2017. "La fotografía móvil y la representación del cuerpo: De la fragmentación al placer visual voyeurístico". Educación Artística: Revista de Investigación (EARI), n. ${ }^{0}$ 8: 165-177. https://doi. org/10.7203/eari.8.10044.

Palumbo, Jacqui. 2020. “The Women Photographers Redefining Surrealism for the 21 st Century". Artsy, 19 de marzo. https://www.artsy.net/ article/artsy-editorial-women-photographers-redefining-surrealism21 st-century.

Pérez Fernández, José Raúl. 2011. "La teoría fotográfica contemporánea: Hacia una nueva pragmática del campo fotográfico". Tesis de doctorado. Universidad Politécnica de Valencia. https://riunet.upv. es/handle/10251/11228
Petrich, Blanche. 2020. "'Desde nosotras', la mirada fotográfica de las mujeres". La Jornada, 3 de marzo. https://www.jornada.com. mx/ultimas/cultura/2020/03/02/encuadres-y-miradas-desdenosotras-6850.html.

Pleyers, Geoffrey. 2018. Movimientos sociales en el siglo XXI: Perspectivas y herramientas analíticas. Buenos Aires: Consejo Latinoamericano de Ciencias Sociales.

Polidoro, Piero. 2016. ¿Qué es la semiótica visual? Bilbao: Universidad del País Vasco.

Porras Laguna, Martha. 2014. "Mujeres fotógrafas en el siglo XXI". https://issuu.com/martaporras/docs/mujeres_fotografas_en_ el_siglo_xxi_.

Victoria Razo. Photojournalist. Acceso 23 de febrero de 2021. http:// www.victoriarazo.com/.

Revilla, Federico. 2012. Diccionario de iconografía y simbología. Madrid: Cátedra.

Reilly, Maura. 2015. "Taking the Measure of Sexism: Facts, Figures, and Fixes". Art News, 26 de mayo. https://www.artnews.com/ art-news/news/taking-the-measure-of-sexism-facts-figures-andfixes-4111/.

Ricoeur, Paul. 2002. Del texto a la acción: Ensayos de hermenéutica II. México: Fondo de Cultura Económica.

Rosales Cueva, José Horacio. 2012. "El iconografema”. En deSignis 20: Semióticas urbanas. Espacios simbólicos, 165-173. Buenos Aires: La Crujía.

Rosenblum, Naomi. 2010. A History of Women Photographers. Nueva York: Abbeville Press.

Sandel, Michel. 2020. La tiranía del mérito: ¿Qué ha sido del bien común? Madrid: Debate.

Senado de la República de México. 2019. "México, primer lugar en abuso sexual infantil". http://comunicacion.senado.gob.mx/ index.php/informacion/boletines/45796-mexico-primer -lugar-enabuso-sexual-infantil.html.

Sheets, Hilarie M. 2016. "Female Artists Are (Finally) Getting Their Turn". New York Times, 29 de mayo. https://www.nytimes. com/2016/04/03/arts/design/the-resurgence-of-women-onlyart-shows.html.

Schwarz, Patricia Karina Natalia. 2016. "Fotografías en el espacio virtual: Aspectos éticos y epistémico-metodológico de su análisis en ciencias sociales". Discursos Fotográficos 12, n. ${ }^{0}$ 20: 63-81. https://ri.conicet.gov.ar/handle/11336/117868.

Sontag, Susan. 2011. Sobre la fotografía. Buenos Aires: Debolsillo.

Torrado Zamora, Laura. 2012. “La representación del cuerpo femenino en la fotografía española: Artistas fotógrafas de la colección de arte contemporáneo del Museo Nacional Centro de Arte Reina Sofía (1990-2010)". Tesis de doctorado. Universidad Complutense de Madrid. https://eprints.ucm.es/id/eprint/15654/. 
Val, Alejandra. 2011. "Imágenes en contexto: Genealogía, representación social e imaginario pictórico del cuerpo femenino". Aisthesis 49: 53-66. http://dx.doi.org/10.4067/S0718-71812011000100003.

Vicente, Alex. 2018. "La fotografía feminista actualiza su legado generacional". El País. https://smoda.elpais.com/feminismo/la-fotografia-feministaactualiza-su-legado-generacional/. 